UDC 343.37(477)

Protsenko Taras, Doctor of Juridical Sciences, Professor, Honored Education Worker of Ukraine, Chief Researcher, State Research Institute MIA Ukraine, Kyiv, Ukraine ORCID ID 0000-0003-0611-5258

\title{
GENERAL AND SPECIFIC FOUNDATIONS FOR PREVENTING CRIMINAL OFFENCES COMMITTED IN THE FIELD OF ECONOMIC ACTIVITY
}

The article studies general and special principles of prevention of crimes committed in the sphere of economic activity. The differentiated approach to definition of "economic crimes" in a domestic science is analyzed. It is justified that high latency of crime in the sphere of economic activity does not allow to be guided by official data, as they do not correspond to the real level of criminal damage to the economic sphere. On the example of crimes in credit-banking activity and crimes related to money laundering, the bases of prevention of these crimes are investigated. It was summed up that such an analysis will help to identify vulnerabilities in the factors causing these crimes.

Keywords: prevention, economic crimes, banking sphere, general principles of preventing.

The advent of new economic conditions leads to the emergence of new ways of committing criminal acts in the sphere of economic activity. The study of the signs of crimes in this area and the analysis of their commission showed that the leading factors of influence were the economic instability in the state and the struggle for economic power.

In terms of social instability and economic decline, the strengthening of structural deformations, a new wave of illegal takeovers, against the background of weakening the real influence of the state on the economy and, in particular, on the financial system, there is a significant increase in the number of mercenary criminal offenses in the field of economic activity. Many facts of illegal obtaining and misuse of preferential bank loans, the outflow of capital into foreign banks and the shadow economy, legalization (laundering) of proceeds of crime were revealed.

Taking into account the urgency of the above, the research of general and special principles of preventing criminal offences committed in the sphere of economic activity, became the purpose of the article.

The variety of ways in which economic crimes are committed, the use of different technologies and operations by criminals, and other factors that contribute to the commission of illegal economic activities lead to significant difficulties in detecting, investigating and preventing them. Therefore, the first step is to determine which crimes should be classified as such.

M. Bazhanov, I. Baziaruk, V. Bilous, S. Kravchuk, A. Lytvak, O. Yakovliev paid attention to the problems of economic crime. A. Medentsev, A. Pchelina, E. Saterlend,

DOI (Article): https://doi.org/10.36486/np.2019.3.16

(C) Protsenko Taras, 2019 
R. Stepaniuk, D. Kharko devoted their works to the criminological aspect of economic crimes.

In domestic science there is a differentiated approach to the definition of crimes in the sphere of economy and economic activity, causes certain difficulties. Notably, "crimes in the sphere of economy", "economic crimes", "shadow economy", "criminal economy", "economic delinquency" and others.

Such attempts identify these concepts and also determine the different nature of their origin. A. Yakovliev considered economic crime as a property and mercenary crime, as well as a crime in the sphere of economy, and characterized economic crime as a set of mercenary encroachments on property, the order of management of the economy, committed by persons occupying certain social positions in the structure of the economy.

S. Kravchuk noted that all these concepts have a different spectrum of illegal acts: crimes in the sphere of economy - mainly economic crimes committed in different spheres; economic crime consists in committing crimes in the sphere of economic activity, including the use of official position.

S. Kravchuk refers to economic crimes as acts related to causing material damage or obtaining material benefit [1]. Summing up the different views of scientists on such crimes, we can highlight their main features: abuse of power; property character; high latency; use of legal and illegal economic activities. Criminal literature identifies a number of illegal acts that constitute economic crimes. These include: violation of antidumping legislation (which indicates crimes related to violation of free competition rules) fraud, release of low-quality products (crimes that violate consumer rights); Securities fraud, accounting fraud, fictitious bankruptcy, use of counterfeit bank documents (crimes based on misuse of investments, deposit capital, which cause significant damage to shareholders, creditors, etc.) [2]. The peculiarity of committing an economic crime is that the subject of such an illegal act is property as capital, and therefore there is an increased organization and use of specific ways of behavior. Another peculiarity of economic crimes can be considered the fact that criminal acts are committed under the guise of various types of civil law transactions, and therefore from the outside they are quite legitimate economic and financial transactions [3, p. 121].

Criminal structures have intensified their activities on a nationwide scale, and law enforcement agencies have, in fact, lost control over the [menacing crime situation in the state. Illegal takeovers are constantly threatening the private property of companies. Raidership becomes an illegal tool for redistribution of property and realization of personal interests.

In Chapter 3 of the National Security Strategy of Ukraine, approved by the Decree of the President of Ukraine as of May 26, 2015, № 287/2015, the current threats to Ukraine's national security are the economic crisis, the exhaustion of the country's financial resources, and declining living standards. One of the reasons for such a threat is the high level of shadowing and criminalization of the national economy, the criminal-crony system of distribution of public resources.

In addition, among the main priorities of the further development of the Ukrainian economy, the fight against crime in the field of business activity is particularly

DOI (Article): https://doi.org/10.36486/np.2019.3.16

(C) Protsenko Taras, 2019 
highlighted, as the European integration course of the state, economic reforms, and financial support of international organizations aimed at bringing the country's economy out of crisis and improving the investment climate can be eliminated in the absence of a stable state institutional mechanism for combating the criminalization of the economy [4].

In recent years, attempts to reform the economy have revealed the most significant crimes in this area, namely: fictitious entrepreneurship and illegal economic activity, criminal offenses committed in banking institutions, in the sphere of manufacturing and circulation of medicines and medical products, crop protection agents (pesticides and agrochemicals), alcoholic beverages, tobacco products, in the field of land relations, state material reserves, in the market for petroleum products, in the sphere of mining and subsoil use, etc.

Therefore, today among the most dangerous criminal areas in the economy, in particular, are: credit and financial relations and banking, branches of production and circulation of medicines, crop protection agents, alcoholic beverages, tobacco products, land relations, relations in the field of formation, storage, maintenance, placement, release, use, replenishment, and renewal of the stocks of the state material reserve, as well as management of the state material reserve, relations in the field of extraction and use of natural resources, relations in the fuel and energy complex.

Using crime in the field of credit and banking activities and money laundering as an example, let us analyze general and specific prevention principles. The priority task of law enforcement authorities, which has become particularly relevant in recent times, is the fight against sham business, the illegal sale of agricultural land, and the prevention of money laundering and counteraction to it. Also, criminal offenses committed in the field of credit and banking activities have become widespread and constitute a significant danger to society and the state.

As you know, the banking system of Ukraine is one of the areas with the most extensive and active use of modern information technologies and the Internet. And given that these technologies are used for money transfers, the financial sphere is of increasing interest in criminal groups.

Crimes committed in the field of credit and banking activities are characterized by considerable diversity, special sophistication, highly intellectual character, an active adaptation of criminals to new forms and methods of business activity, application of bank documents, new electronic payment facilities, communications facilities, as well as new banking technologies for economic activities.

Unauthorized debiting of bank accounts, fraud with payment cards, interference with the work of Internet banking, the spread of computer viruses, and fraud in information networks of banks - an inexhaustible list of crimes in the banking sector.

In particular, the most common methods of stealing money from banking institution include: issuing bank loans to borrowers affiliated with owners of banking institutions; bank loans issued to enterprises with signs of fictitiousness; withdrawal of property from bail through the transfer of ownership to a third party; withdrawal of funds through correspondent accounts in foreign banks. Thus, banks can lend their shareholders through ambiguous financial schemes.

At the same time, in recent years, the emphasis in banking institutions has shifted considerably from offenses related to lending to the cash (bank 48 resources) outflow abroad, money laundering, committing crimes in the field of online banking $(\mathrm{OB})$, and illegal transfer of funds using counterfeit payment orders, etc.

DOI (Article): https://doi.org/10.36486/np.2019.3.16

(C) Protsenko Taras, 2019 
According to the Exchange-online system of the Ukrainian Interbank Payment Systems Member Association "EMA" (EMA Association), the most common types of fraud in the banking sector are: ATM fraud, Internet fraud, OB fraud, fraud in the acquiring network, and fraud using methods of social engineering [5].

The most vulnerable for criminal offenses in the banking sector are online services or remote access services for customers to their own accounts in banks, "electronic wallets" with added card accounts.

In particular, due to the globalization of financial systems, international banking networks are developing and electronic trading operations are spreading, which also has negative consequences in the form of creating favourable conditions for manipulating financial instruments in order to evade taxation and legalization (laundering) of proceeds of crime, in particular through transfer pricing [6].

It should be noted that most of the criminal schemes in the Ukrainian economy are impossible without the attraction and direct involvement of banks. Often, bank officials act in the interests of offenders. In many banks, offenders open accounts for fictitious transactions, convert and transfer cashless funds into cash.

Shadow banking has become widespread in Ukraine, which should include not only financial market institutions that are not regulated by banking supervisors but also those financial intermediaries who have signs of traditional shadow activities associated with illegal transfer of capital, money laundering, and cash currency transactions (so-called currency exchange offices). Participants of shadow banking in their illegal financial (currency) activities actively use the cryptocurrency system.

Also, the shadow currency market has developed at the level of the banking system as a whole. In essence, the banking system serves both legal and shadow foreign exchange markets in parallel. This scheme works as follows: large exporters agree with banks on the purchase of currency in accordance with the NBU requirements, but at a lower official exchange rate and subject to the sale of this currency to specific importers. By purchasing this currency, importers compensate exporters for the difference between the official exchange rate and the shadow market rate, paying a commission to banks.

Since the Ukrainian financial system is focused on the cash-based form of payments, therefore, in order that employees of law-enforcement agencies timely and efficiently identify crimes committed in the field of economic activity, it is expedient to pay significant attention to the issue of cash circulation. In particular, the illegal transfer of cashless funds into cash with its subsequent withdrawal from the country is one of the most widespread types of illegal business - the so-called "currency conversion centres." Such firms have fictitious signs, are registered on front parties, do not report to the tax authorities and, for the reward, "provide services" of cash conversion.

Active participants in currency conversion operations are banking institutions. Banks can monetize funds through conversion centres and using fly-by-night companies. Moreover, some banks have created special conversion centres for the transfer of legal funds to the "shadow" and, conversely, from the illegal sector to the legal one.

In this case, the main tools used in the schemes of taking over and legalization of funds received as a result of their theft from banking institutions are: "garbage" securities; debt obligations of enterprises with fictitious signs; transfer of claim right; cash conversion.

Mostly conversion centres are created by a criminal group of individuals who have significant experience in this activity and are closely linked to credit and

DOI (Article): https://doi.org/10.36486/np.2019.3.16

(C) Protsenko Taras, 2019 
financial (banking) institutions. Such a mechanism guarantees the security of the implementation of schemes for the further laundering of "dirty" money. As a result, organized crime groups primarily use the credit and banking system to legalize (launder) the proceeds of crime, precisely through the creation of fictitious firms.

The consequences of the activities of fictitious companies in Ukraine became threatening. So, according to the estimates of the Ministry of Economic Development and Trade, in 2017, the level of the shadow economy amounted to $33 \%$ of the official GDP, in $2016-34 \%$ of the official GDP [7]. At the same time, despite the statements of the leaders of law enforcement authorities on the disclosure of hundreds and thousands of fictitious business entities every year, statistical data testify to the opposite: the number of sentences under Art. 205 of the Criminal Code of Ukraine ("Fictitious Entrepreneurship") is extremely low.

In January 2018, in the report of the Committee of Experts on the Evaluation of Anti-Money Laundering Measures and the Financing of Terrorism (MONEYVAL) of the Council of Europe about Ukraine, it was stressed that "Ukraine faces significant risks in terms of money laundering through corruption and illegal economic activity, including fictitious business, tax evasion, and fraud" [8]

In the process of "dirty" money laundering, the insurance market is widely used. The most widespread ways to launder criminal incomes through the insurance market include: obtaining by an insurance company cash for unlikely insurance risks, followed by transfer in favour of enterprises with fictitious signs; carrying out a significant number of financial reinsurance operations with insurance companies that have an unsatisfactory financial position; crediting by the insurance company of significant sums of funds in favour of individuals as payments for agency agreements; an insurance company's payment of the insurance indemnity within a short period to a significant number of individuals.

Along with this, in relation to the considerable development of computer and information technologies, electronic exchanges have been operating in Ukraine for quite a long time. Control over the organizations that provide Internet trading services is not implemented properly; some markets have unrestricted access, as a result of which it finds itself out of the control area, and in the territory of Ukraine, fictitious companies are emerging who represent themselves as dealing centres.

Therefore, it should be noted that crime in the field of economic activity requires effective offensive, namely, the use of effective means of detection and prevention of the specified types of criminal offenses; elimination of the causes and conditions of economic crime. That is, the disclosure of such crimes requires the development and application of scientifically grounded methods. In addition, the harmonization of Ukrainian legislation and the coherence of methods and means of operational and investigative activities and criminal procedural norms are relevant in this issue.

The extremely high latency of crime in the field of economic activity does not allow relying on official data since they do not correspond to the real level of criminal damage to the economic sphere. Moreover, although they reflect the activity or effectiveness of activities of individual law enforcement agencies in detecting and documenting criminal offenses in the economic field, they do not indicate a low level of selfish economic criminal activity.

DOI (Article): https://doi.org/10.36486/np.2019.3.16

(C) Protsenko Taras, 2019 
High concealment of crimes in the field of economic activity is characterized by a number of factors. In addition, in terms of multi-factor burdensome accounting and control system, it is difficult to establish channels and mechanisms for the acquisition of state and other property.

With the purpose of developing effective methods for detecting and preventing criminal offenses in the field of economic activity, there is a need for systematic detailed consideration of the most common criminal manifestations in various sectors and spheres of business activity. It is this analysis that will help to find vulnerabilities in the factors that cause these crimes, which in the long run can be a guarantee of a successful fight not only with them but also with the crimes committed in the above and other sectors and spheres of economic activity.

\section{REFERENCES}

1. Kravchuk S. (2009). "Economic Crime in Ukraine" available at: http://westudents.com.ua/ knigi/116- ekonomchna-zlochinnst-v-ukran-kravchuk-sy.html (date of application: 18.02.2018) [in English].

2. Kharko D.M. (2010). "Criminological problems in determining the concept and features of modern economic crime as a factor of shadow economy of Ukraine" available at: http://www.apdp.in.ua/ v55/119.pdf (date of application: 18.02.2018) [in English].

3. Pchelina O.V. (2009). "Mechanism of committing economic crimes", Law and Safety, vol. 4. P. 118"122. [in English].

4. Maslii I.V. (2015). Instytutsiinyi mekhanizm protydii kryminalizatsii ekonomiky: kryminolohichne doslidzhennia, kand.. dosl. "Institutional mechanism of economics: a criminological study". Odesa [in Ukrainian].

5. Danylchenko O. Tendentsyi platezhnoho moshennychestva v Ukrane. "Payment fraud trends in Ukraine.”. URL: http://ema.com.ua/wp-content/uploads/2014/10/material_02_10_2014_exchange_ online.pdf [in Russian].

6. Tyshchuk T.A., Kharashvili Yu.M., Yvanov O.V. (2011). Tinova ekonomika v Ukraini: masshtaby ta napriamy podolannia: analit.dok. Kyiv: NISD [in Ukrainian].

7. Tanasiienko N.P. (2017). Otsinka zahroz ekonomichnii bezpetsi Ukrainy yak skladovoi natsionalnoi bezpeky. "Assessment of threats to the economic security of Ukraine as a component of national security”. Economics and Society: Mukachevo National University, p. 136-141 [in Ukrainian].

8. Korupciia ta tinova ekonomika "vymyvaiut" ghroshi z Ukrainy - Rada Yevropy. "Corruption and the shadow economy are "washed out" by money from Ukraine - the Council of Europe". Retrieved from https://www.epravda.com.ua/news/2018/01/30/633536/ [in Ukrainian].

УДК 343.37(477)

Проценко Тарас Олександрович, доктор юридичних наук, професор, головний науковий співробітник ДНДІ МВС України, м. Київ, Україна, ORCID ID 0000-0003-0611-5258

\section{ЗАГАЛЬНІ ТА СПЕЦІАЛЬНІ ЗАСАДИ ЗАПОБІГАННЯ КРИМІНАЛЬНИМ ПРАВОПОРУШЕННЯМ, ЩО ВЧИНЯЮТЬСЯ У СФЕРІ ГОСПОДАРСЬКОЇ ДІЯЛЬНОСТІ}

У статті досліджено загальні та спеціальні засади запобігання злочинам, що вчиняються у сфері господарської діяльності. Проаналізовано диференційний 
підхід до визначення “економічні злочини” у вітчизняній науці. Обгрунтовано, що висока латентність злочинності у сфері господарської діяльності не дозволяє орієнтуватися на офіційні дані, оскільки вони не відповідають реальному рівню кримінальної ураженості економічної сфери.

Основний акцент дослідження зроблено на розгляді тих сфер та галузей економіки, в яких кримінальні прояви отримали найбільше розповсюдження, в результаті наголошується про розповсюдженість злочинів, що вчиняються у сфері кредитно-банківської діяльності, та злочинів, пов’язаних із легалізацією доходів, одержаних злочинним шляхом, діяльністю фіктивних фірм та конвертаційних центрів.

Вивчення найбілыш криміналізованих сфер та галузей економіки дозволило дійти висновку, що злочинність у сфері господарської діяльності потребує дієвого наступу, а саме: застосування ефективних засобів виявлення та попередження зазначених видів кримінальних правопорушень; усунення причин та умов виникнення економічної злочинності. Наголошується, що розкриття таких злочинів вимагає розробки та застосування науково обгрунтованих методик їх викриття.

На прикладі злочинів у кредитно-банківській діяльності та злочинів, пов’язаних із легалізацією доходів, одержаних злочинним шляхом, досліджено засади запобігання цим злочинам. Акцентовано, що висока прихованість злочинів у сфері господарської діяльності характеризується низкою чинників. В умовах багатофакторної обтяжливої системи обліку та контролю важко встановлювати канали і механізми заволодіння державним та іншим майном.

Підсумовано, що з метою формування ефективних методик виявлення та попередження кримінальних правопорушень у сфері господарської діяльності виникає необхідність систематичного детального розгляду найбільш розповсюджених кримінальних проявів у різних галузях та сферах господарської діяльності. Саме такий аналіз допоможе знайти вразливі моменти в чинниках, що спричиняють ці злочини, та в перспективі може бути запорукою успішної боротьби не лише 3 ними, а й зі злочинами, які вчиняються в інших галузях та сферах господарської діяльності.

Ключові слова: запобігання, економічні злочини, банківська сфера, загальні засади запобігання.

Отримано 10.09.2019

DOI (Article): https://doi.org/10.36486/np.2019.3.16

(C) Protsenko Taras, 2019

Issue 3(4.5) 2019

http://naukaipravoohorona.com/ 